\title{
Analysis of Heavy Metal Contents of Marsilea crenata Presl. Leaves and Soils from East Java Province, Indonesia
}

\author{
Mangestuti Agil' ${ }^{\text {, Hening Laswati }}{ }^{2}$, Neny Purwitasari' ${ }^{1}$, Burhan Ma'arif ${ }^{3, *}$
}

\section{Mangestuti Agil', Hening Laswati ${ }^{2}$, Neny Purwitasari ${ }^{1}$, Burhan Ma'arif ${ }^{3, *}$}

'Department of Pharmacognosy and Phytochemistry, Faculty of Pharmacy, Universitas Airlangga, Surabaya, INDONESIA ${ }^{2}$ Department of Physical Medicine and Rehabilitation, Faculty of Medicine, Universitas Airlangga, Surabaya, INDONESIA ${ }^{3}$ Department of Pharmacy, Faculty Medical and Health Science, Maulana Malik Ibrahim State Islamic University, Malang, INDONESIA.

\section{Correspondence}

\section{Burhan Ma'arif}

Department of Pharmacy, Faculty of Medical and Health Science, Maulana Malik Ibrahim State Islamic University, Malang, INDONESIA

Phone no: (+62) 81335555725

E-mail: burhan.maarif@farmasi.uin-malang. ac.id

\section{History}

- Submission Date: 27-08-2020:

- Review completed: 05-10-2020;

- Accepted Date: 12-10-2020

\section{DOI : 10.5530/pj.2021.13.3}

Article Available online http://www.phcogj.com/v13/i1

\section{Copyright}

(c) 2021 Phcogj.Com. This is an open access article distributed under the terms of the Creative Commons Attribution 4.0 International license.

\begin{abstract}
Introduction: Marsilea crenata Presl. grows in East Java Province, Indonesia, and showed several pharmacological activities due to its phytoestrogen content. Research indicated its phytoremediation property, and therefore has an impact on heavy metal accumulation in the plants. Lead, cadmium, and mercury are amongst heavy metals that are toxic to the human body. This study aimed to determine and compare $\mathrm{Pb}, \mathrm{Cd}$, and $\mathrm{Hg}$ mineral contents of soils and leaves of the plants grew in Batu, Pasuruan, Surabaya, and Kediri cities in the province. Method: $10 \mathrm{~g}$ of dried powdered leaves and soils were put in separate crucible porcelains, and add $2 \mathrm{ml}$ of nitric acid. All were burnt in low heat until white smoke were not formed, and then stood to cool. Ashes obtained were examined using AA 6200 Atomic Absorption Spectrometer (AAS). Result: Showed that leaves samples from the areas showed no Pb and $\mathrm{Hg}$ mineral contents that exceeded the permissible limit. Batu City leaf sample had Cd heavy metal content of $2.79 \pm 0.01$ ppm, which exceeded the permissible limit. Conclusion: Analysis of heavy metal contents of soils from all of the areas showed no exceed limit of $\mathrm{Pb}$ and $\mathrm{Hg}$ mineral concentrations. Cd soil contents of Surabaya and Kediri cities, were $0.73 \pm 0.00$ and $2.61 \pm 0.08$ ppm respectively.
\end{abstract}

Key words: AAS, Clover, Phytoremediation.

\section{INTRODUCTION}

Marsilea crenata Presl. is an aquatic plant and has been used through generations by people of Surabaya City and East Java Province of Indonesia as vegetables. Through unknown resources, it was known that Marsilea crenata Presl. leaves had antiosteoporosis property among post-menopausal women, and therefore scientific research were being conducted to prove it. A research showed that Marsilea crenata Presl. leaves had activity in bone formation in an in vitro study using MC3T3-E1 cell line and in vivo in female mice ${ }^{1,2}$. Further research was conducted to study the neuroprotective activity of the leaves by inhibition of neuroinflammation in prolonged activation of microglia HMC3 cell line classical pathway, ${ }^{3,4}$.

Research revealed, that such activities are caused by the phytoestrogen content of leaves ${ }^{1,3,5,6}$, through its binding affinity to estrogen receptors (ERs) of cells $s^{7,8}$. Phytoestrogen is a group of compounds of plants with either estrogen-like structure or estrogenic function, and can bind to the receptor through ER dependent or ER-independent pathways $^{9-11}$.

On the other hand, the plant has heavy metal phytoremediation property ${ }^{12}$. An unpublished research revealed high lead and mercury concentrations of powdered leaves of plants cultivated in water in its original habitat in East Java. It proved the phytoremediation property of the plant. The phytoremediation capability has an impact on heavy metal accumulation in the plants, and is critical for human consumption ${ }^{13}$.
Lead $(\mathrm{Pb})$, cadmium $(\mathrm{Cd})$, and mercury $(\mathrm{Hg})$ are examples of heavy metal that are toxic to human. The average $\mathrm{Pb}$ rate of absorption for adults is 10 to $15 \%$ of the total consumption, and this amount can increase to $50 \%$ among infants, young children and pregnant women ${ }^{14}$. Animal study showed the absorption range of $\mathrm{Cd}$ from the intestine between $0.5 \%$ to $3 \%{ }^{15}$, but so far no information on the correlation of the blood or urine $\mathrm{Cd}$ content with its clinical toxicity ${ }^{16}$. Lead is mostly accumulated in blood, and symptoms of poisoning occurred when it reached a level of blood concentration of $0.2-0.6 \mathrm{ppm}$. Such concentration could be reached through daily intake of $0.3-1.0 \mathrm{mg}$ of $\mathrm{Hg}$ among healthy men ${ }^{17}$.

Soil heavy metal pollution has become a worldwide environmental issue that has attracted considerable public attention, largely from the increasing concern for the security of agricultural products. Heavy metals enter the soil agro-ecosystem through natural processes derived from parent materials, and through anthropogenic activities, and it can accumulate in the soil ${ }^{18}$. Therefore, further research is needed to study more on the areas of cultivation of the plant to find a better leaf quality free of toxic heavy metal pollution.

This study aims to determine and compare $\mathrm{Pb}, \mathrm{Cd}$, and $\mathrm{Hg}$ contents of Marsilea crenata Presl. leaves and soils of selected areas from Kediri, Batu, Pasuruan, and Surabaya Cities as some of the areas where the plant grows abundantly in East Java Province, Indonesia. Determination is based on the Indonesian National Food and Drug Agency Regulatory No. 12, $2014^{19}$, and World Health Organization ${ }^{20}$ heavy metal permissible limits. Selection of areas is also based on the altitude of each place that cause differences 
in temperature and rainfall. Those are among external factors that influence varieties of secondary metabolites and affect the plant phytoremediation property ${ }^{21}$.

\section{MATERIALS AND METHOD}

\section{Materials}

\section{Plant and soil materials}

Marsilea crenata Presl. leaves were collected from Batu District of Batu City, Purwodadi District of Pasuruan City, Benowo District of Surabaya City, and Wates District of Kediri City. All districts had different temperatures, altitudes and rain falls (Table 1). All leaves were identified in Center for Plant Determination, Unit Pelaksana Teknis, Materia Medica, Batu, Indonesia, under specimen number 1a-17b18a-1. The leaves were harvested at 14 days of age, as can be seen from the color, that was dark green, and the size, that was $2 \mathrm{~cm}$ in diameter (Figure 1).

The leaves were dried and powdered, while the soils from each selected area where plants grew were taken and analyzed for heavy metal contents.

\section{Chemical materials}

Standard solutions of $\mathrm{Pb}, \mathrm{Cd}$, and $\mathrm{Hg}$ (Merck), $\mathrm{HNO}_{3}$ (Merck), and aquadestilata (Merck) were purchased from Chemical Analysis and Measurement Unit, Faculty of Mathematics and Natural Science, Brawijaya University, Indonesia.

\section{Method}

Heavy metal analysis of Marsilea crenata Presl. leaves and the soil

Each standard of heavy metal was diluted with various solution. Cd and $\mathrm{Pb}$ were diluted with $\mathrm{HNO}_{3} 1 \%$ and $\mathrm{Hg}$ with aquadestilata as solvents. Each solution was prepared in concentrations of $0.05 ; 0.1 ; 0.25 ; 0.5$; and $1 \mathrm{ppm}$. Samples of 10 grams of dried powdered leaves and soils were put in separate crucible porcelains, and burnt carefully at low heat to decomposed. During this process all crucible porcelain should be covered tightly. $2 \mathrm{ml}$ of nitric acid then were added into each of the crucible porcelain, and continued heating at $500^{\circ} \mathrm{C}$ up to $600^{\circ} \mathrm{C}$ until white smoke was no longer formed. All samples were remove from heat and stood to cool, and then remove to $25-\mathrm{ml}$ measuring flasks. Samples for $\mathrm{Pb}$ and $\mathrm{Cd}$ identifications were dissolved in $1 \% \mathrm{HNO}_{3}$, while for $\mathrm{Hg}$ identification in aquadestilata. All were then filtered with ash-free filter papers, and examined with AA 6200 Atomic Absorption Spectrometer (AAS) (Shimadzu, Japan) to calculate the concentration of $\mathrm{Pb}, \mathrm{Cd}$, and $\mathrm{Hg}^{23}$.

\section{RESULTS}

\section{Heavy metal analysis of Marsilea crenata Presl. leaves}

Results of AAS analysis on the heavy metal contents of Marsilea crenata Presl. leaves from Batu, Purwodadi, Benowo, Wates Districts, East Java Province, Indonesia are as follows (Table 2).

Based on the WHO guidelines and Indonesian National Food and Drug Agency Regulatory, Batu District showed $\mathrm{Pb}$ and $\mathrm{Hg}$ concentrations within the permissible limits, while $\mathrm{Cd}$ concentration was exceeded the limit. Purwodadi, Benowo, and Wates Districts showed $\mathrm{Pb}, \mathrm{Cd}$, and $\mathrm{Hg}$ concentrations within the permissible limits. It was shown that, Batu District was the only area in the study to have heavy metal content exceeded the permissible limit, that is $\mathrm{Cd}$, with concentration of 2.79 ppm.

\section{Heavy metal analysis of soils}

Results of AAS analysis on the heavy metal contents of soils from Batu, Purwodadi, Benowo, Wates Districts, East Java Province, Indonesia were as follows (Table 3).

Soil samples from all areas were within the permissible limits of $\mathrm{Pb}$ and $\mathrm{Hg}$ concentrations. Batu and Purwodadi Districts showed $\mathrm{Pb}, \mathrm{Cd}$, and $\mathrm{Hg}$ concentrations within the permissible limits. Benowo and Wates Districts showed exceeding limit of Cd concentrations.

A comparison between $\mathrm{Pb}, \mathrm{Cd}$ and $\mathrm{Hg}$ mineral contents and concentrations of leaves and soils of Batu, Purwodadi, Benowo, Wates Districts, East Java Province, Indonesia was described as follows (Table 4).

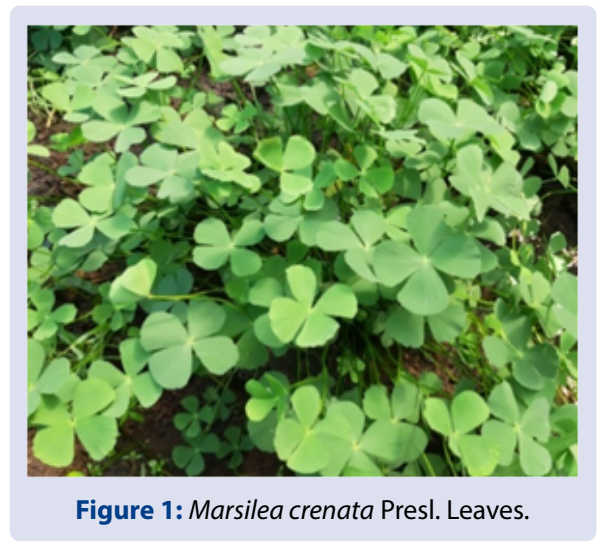

Table 1: Demography of areas of cultivation of Marsilea crenata Presl.

\begin{tabular}{|c|c|c|c|c|c|}
\hline No. & Area & Soil Type & Elevation (masl) & Rainfall/Year (mm) & Temperature $\left({ }^{\circ} \mathrm{C}\right)$ \\
\hline 1. & Batu District, Batu City & Andosol & $900-1000$ & $2001-2500$ & $24-26$ \\
\hline 2. & $\begin{array}{l}\text { Purwodadi District, Pa- } \\
\text { suruan City }\end{array}$ & Alluvial & $350-700$ & $2001-2500$ & $25-32$ \\
\hline 3. & $\begin{array}{c}\text { Benowo District, Surabaya } \\
\text { City }\end{array}$ & Alluvial & $20-30$ & $1001-1500$ & $24-32$ \\
\hline 4. & Wates District, Kediri City & Regosol & $50-60$ & $15001-2000$ & $23-30$ \\
\hline
\end{tabular}

(Indonesian National Meteorology, Climatology, Geophysics Agency, 2019)22 
Table 2: Heavy metal contents of Marsilea crenata Presl. leaves from Batu, Purwodadi, Benowo, Wates Districts, East Java Province, Indonesia.

\begin{tabular}{|c|c|c|c|c|}
\hline \multirow{2}{*}{ No. } & \multirow{2}{*}{ Area } & \multicolumn{3}{|c|}{$\begin{array}{l}\text { Heavy Metal Concentration } \\
\text { (ppm) }\end{array}$} \\
\hline & & $\begin{array}{c}\mathrm{Pb} \\
(\text { limit }<10 \text { ppm) }\end{array}$ & $\begin{array}{c}C d \\
\text { (limit }<0,3 \text { ppm) }\end{array}$ & $\begin{array}{c}\mathrm{Hg} \\
(\text { limit }<0,5 \mathrm{ppm})\end{array}$ \\
\hline 1. & Batu District, Batu City & 0.00 & $2.79 \pm 0.01^{*}$ & 0.00 \\
\hline 2. & Purwodadi District, Pasuruan City & 0.00 & 0.00 & 0.00 \\
\hline 3. & Benowo District, Surabaya City & $1.06 \pm 0.01$ & 0.00 & 0.00 \\
\hline 4. & Wates District, Kediri City & 0.00 & 0.00 & 0.00 \\
\hline
\end{tabular}

*Exceed the safe limit from Indonesian National Food and Drug Agency Regulatory and WHO Guideline

Permissible limits of Indonesian National Food and Drug Agency Regulatory No. 12/2014: Pb 10 ppm, Cd 0.3 ppm, and Hg 0.5 ppm,

Permissible limits of WHO Guideline: $\mathrm{Pb} 10$ ppm, Cd 0.3 ppm, and $\mathrm{Hg} 0.5$ ppm.

Table 3: Heavy metals contents in soil samples from Batu, Purwodadi, Benowo, Waters Districts, East Java Province, Indonesia.

\begin{tabular}{|c|c|c|c|c|}
\hline \multirow{2}{*}{ No. } & \multirow{2}{*}{ Area } & \multicolumn{3}{|c|}{$\begin{array}{l}\text { Heavy Metal Concentration } \\
(\mathrm{ppm})\end{array}$} \\
\hline & & $\begin{array}{c}\mathrm{Pb} \\
(\text { limit }<10 \text { ppm) }\end{array}$ & $\begin{array}{c}\mathrm{Cd} \\
\text { (limit }<0,3 \mathrm{ppm})\end{array}$ & $\begin{array}{c}\mathrm{Hg} \\
(\text { limit }<0,5 \mathrm{ppm})\end{array}$ \\
\hline 1. & Batu District, Batu City & $6.60 \pm 0.21$ & 0.00 & 0.00 \\
\hline 2. & Purwodadi District, Pasuruan City & $2.77 \pm 0.10$ & 0.00 & 0.00 \\
\hline 3. & Benowo District, Surabaya City & $3.30 \pm 0.10$ & $0.73 \pm 0.00^{*}$ & 0.00 \\
\hline 4. & Wates District, Kediri City & 0.00 & $2.61 \pm 0.08^{*}$ & 0.00 \\
\hline
\end{tabular}

*Exceed the safe limit from Indonesian National Food and Drug Agency Regulatory and WHO Guideline

Permissible limits of Indonesian National Food and Drug Agency Regulatory No. 12/2014: Pb 10 ppm, Cd 0.3 ppm, and Hg 0.5 ppm

Permissible limits of WHO Guideline: $\mathrm{Pb} 10$ ppm, Cd 0.3 ppm, and $\mathrm{Hg} 0.5$ ppm.

Table 4: Pb, Cd and Hg mineral contents of leaves and soils of Batu, Purwodadi, Benowo, Wates Districts, East Java Province, Indonesia.

\begin{tabular}{|c|c|c|c|c|c|c|c|}
\hline \multirow{3}{*}{ No. } & \multirow{3}{*}{ Area } & \multicolumn{6}{|c|}{$\begin{array}{l}\text { Heavy Metal Concentration } \\
\text { (ppm) }\end{array}$} \\
\hline & & \multicolumn{3}{|c|}{ Leaf } & \multicolumn{3}{|c|}{ Soil } \\
\hline & & $\begin{array}{c}\mathrm{Pb} \\
(\text { limit }<10 \mathrm{ppm})\end{array}$ & $\begin{array}{c}\mathrm{Cd} \\
\text { (limit }<0,3 \mathrm{ppm})\end{array}$ & $\begin{array}{c}\mathrm{Hg} \\
\text { (limit }<0,5 \mathrm{ppm})\end{array}$ & $\begin{array}{c}\mathrm{Pb} \\
(\text { limit }<10 \mathrm{ppm})\end{array}$ & $\begin{array}{c}\text { Cd } \\
\text { (limit }<0,3 \text { ppm) }\end{array}$ & $\begin{array}{c}\mathrm{Hg} \\
\text { (limit }<0,5 \mathrm{ppm})\end{array}$ \\
\hline 1. & Batu District, Batu City & 0.00 & $2.79 \pm 0.01^{*}$ & 0.00 & $6.60 \pm 0.21$ & 0.00 & 0.00 \\
\hline 2. & Purwodadi District, Pasuruan City & 0.00 & 0.00 & 0.00 & $2.77 \pm 0.10$ & 0.00 & 0.00 \\
\hline 3. & Benowo District, Surabaya City & $1.06 \pm 0.01$ & 0.00 & 0.00 & $3.30 \pm 0.10$ & $0.73 \pm 0.00^{*}$ & 0.00 \\
\hline 4. & Wates District, Kediri City & 0.00 & 0.00 & 0.00 & 0.00 & $2.61 \pm 0.08^{*}$ & 0.00 \\
\hline
\end{tabular}

*Exceed the safe limit from Indonesian National Food and Drug Agency Regulatory and WHO Guideline

Permissible limits of Indonesian National Food and Drug Agency Regulatory No. 12/2014: Pb 10 ppm, Cd 0.3 ppm, and Hg 0.5 ppm,

Permissible limits of WHO Guideline: $\mathrm{Pb} 10$ ppm, Cd 0.3 ppm, and $\mathrm{Hg} 0.5$ ppm.

\section{DISCUSSION}

Phytoremediation is an ecological strategies of plants, in situ, to promote the breakdown, immobilization, and removal of pollutants from the environment. Some plants showed their ability in conducting phytoextractions, thus enable to control heavy metal contents of soil. The effectiveness of the extraction process could determine the concentration of accumulated heavy metals in various plant tissues, such as leaves, roots and other plant cells ${ }^{21}$.

This study was aimed to compare the contents of heavy metals found in plant leaves and in the soil where the plants grew. Through Cd analysis, only leaves from Batu District of Batu city, was 2.79 ppm, which exceeded the limit. But, analyses of soil showed that Cd concentration of Batu District was within the permissible limit. This indicated a possibility of the occurrence of phytoremediation through the air, that is via the absorption of $\mathrm{Cd}$ particles from the air, and accumulated in the leaves. Therefore, there were no absorption of the metal from the $\operatorname{root}^{24-25}$.

Benowo and Wates Districts showed exceed limit of Cd content of the soils, while in leaves were within the permissible limits. One of the probabilities of such occurrence is the self-defense mechanism of the plants against heavy metal absorption from the root through the secretion of exudates into the soil matrix. Such secretion is considered the first line of self-defense mechanism against heavy metal, in which root exudates play a major role in the chelation of the metal, so as to prevent their uptake by the cells $\mathrm{s}^{26-27}$.

This mechanism might caused low $\mathrm{Pb}$ content of leaves from all areas in the study, even though $\mathrm{Pb}$ occurred in the soils where the plants grew. In this case, there was a probability that $\mathrm{Pb}$ was converted into chelate forms by root exudates as a self-defense mechanism. Through analysis, $\mathrm{Hg}$ content was not found in the leaves and soil of the areas where the plants grew.

Result of the study indicated, that Purwodadi District of Pasuruan city could be considered as the most suitable area for the cultivation of Marsilea crenata Presl. This is because of the free heavy metal contamination of $\mathrm{Pb}$ and $\mathrm{Cd}$ contents of the leaves and soils, while $\mathrm{Pb}$ content of soil was within permissible limit. Purwodadi District also is located in an area with heavy rainfall per year compared to other areas. There is a possibility that heavy rainfall could help to clean the soil from heavy metal contamination, while high temperature of the area helped 
to enhance the self-defense mechanism of the plant. Enhancement of self defense mechanism helped in reducing the amount of heavy metal absorption by the roots ${ }^{26,28}$.

\section{CONCLUSION}

Based on the analysis of heavy metal contents of $\mathrm{Cd}, \mathrm{Hg}$, and $\mathrm{Pb}$ of Marsilea crenata Presl. leaves and soils in Batu, Purwodadi, Benowo, Wates Districts, East Java Province, Indonesia, it can be concluded that Purwodadi District, Pasuruan City, is recommended for the cultivation of Marsilea crenata Presl.

\section{ACKNOWLEDGEMENTS}

This research was supported and funded by Penelitian Unggulan Fakutas Program, Faculty of Pharmacy, Universitas Airlangga, Surabaya, Indonesia.

\section{CONFLICTS OF INTEREST}

The author states that there is no conflicts of interest with the parties involved in this study.

\section{REFERENCES}

1. Agil M, Ma'arif B, Aemi NY. Aktivitas antiosteoporosis fraksi n-heksana daun Marsilea crenata Presl. dalam meningkatkan kepadatan tulang trabekular vertebra mencit betina. Jurnal Tumbuhan Obat Indonesia. 2018;11(2):1-7.

2. Ma'arif B, Agil M, Laswati H. Alkaline phosphatase activity of Marsilea crenata Presl. extract and fractions as marker of MC3T3-E1 osteoblast cell differentiation. Journal of Applied Pharmaceutical Science. 2018;8(03):55-9.

3. Ma'arif B, Mirza DM, Suryadinata A, Muchlisin MA, Agil M. Metabolite profiling of $96 \%$ ethanol extract from Marsilea crenata Presl. leaves using UPLC-QToFMS/MS and anti-neuroinflammatory predicition activity with molecular docking. J. Trop. Pharm. Chem. 2019;4(6).

4. Ma'arif B, Agil M, Laswati H. The enhancement of Arg1 and activated ER $\beta$ expression in microglia HMC3 by induction of $96 \%$ ethanol extract of Marsilea crenata Presl. leaves. Journal of Basic and Clinical Physiology and Pharmacology. 2020;30(6):20190284.

5. Laswati H. Green clover Potentiates delaying the Increment of imbalance bone remodeling process in postmenopausal women. Folia Medica Indonesiana. 2011;47:112-7.

6. Ma'arif B, Mirza DM, Hasanah M, Laswati H, Agil M. Antineuroinflammation activity of $n$-butanol fraction of Marsilea crenata Presl. in microglia HMC3 cell line. Journal of Basic and Clinical Physiology and Pharmacology. 2020;30(6):20190255

7. Cos P, De BruyneT, Apers S, Berghe DV, Pieters L, Vlietinck AJ. Phytoestrogens: recent developments. Planta medica. 2003;69(07):589-99.

8. de Villiers TJ. Bone health and osteoporosis in postmenopausal women. Best Practice \& Research Clinical Obstetrics \& Gynaecology. 2009;23(1):73-85.

9. Ososki AL, Kennelly EJ. Phytoestrogens: a review of the present state of research. Phytotherapy Research: An International Journal Devoted to Pharmacological and Toxicological Evaluation of Natural Product Derivatives. 2003;17(8):845-69.
10. Yang TS, Wang SY, Yang YC, Su CH, Lee FK, Chen SC, et al. Effects of standardized phytoestrogen on Taiwanese menopausal women. Taiwanese Journal of Obstetrics and Gynecology. 2012;51(2):229-35

11. Cui J, Shen Y, Li R. Estrogen synthesis and signaling pathways during aging from periphery to brain. Trends in molecular medicine. 2013;19(3):197-209.

12. Purakayastha TJ, Chhonkar PK. Phytoremediation of heavy metal contaminated soils. Berlin Heidelberg: Springer; 2010.

13. Agil M, Kusumawati I, Purwitasari NN. Phenotypic variation profile of Marsilea crenata Presl. cultivated in water and in the soil. Hindawi Journal of Botany. 2017.

14. Markowitz M. Lead poisoning. Pediatr Rev. 2000;21:327-35.

15. Friberg L, Piscator M, Nordberg GF, Kjellstrom T. Cadmium in the Environment. 2nd Ed. Cleveland: CRC Press; 1974.

16. Bernhoft RA. Cadmium toxi and treatment. Hindawi Publishing Corporation The Scientific World Journal. 2013.

17. Volesky B, Naja GM. Toxicity and sources of $\mathrm{Pb}, \mathrm{Cd}, \mathrm{Hg}, \mathrm{Cr}, \mathrm{As}$, and radionuclides in the environment. Taylor \& Francis Group, LLC. 2009.

18. Alsbou EMA, Al-Khashman OA. Heavy metal concentrations in roadside soil and street dust from Petra region, Jordan. Environmental Monittoring Assessment. 2018;190:48.

19. Indonesian National Food and Drug Agency. Regulatory No. 12 2014. Traditional medicine quality requirements. Regulation of the head of Food and drug control agency of Indonesia. Jakarta: Indonesian National Food and Drug Agency; 2014.

20. WHO. Quality control methods for medicinal plant materials. Geneva: WHO; 1998.

21. Shrestha P, Korkmaz B, Josef HG. Phytoremediation of heavy metalcontaminated soil by switchgrass: a comparative study utilizing different composts and coir fiber on pollution remediation, plant productivity, and nutrient leaching.International Journal of Environtmental Research and Public Health. 2019;16:1261.

22. Indonesian National Meteorology, Climatology, Geophysics Agency. East Java Demography. Jakarta: Indonesian National Meteorology, Climatology, Geophysics Agency; 2019.

23. Tuzen M. Determination of heavy metals in soil, mushroom and plant samples by atomic absorption spectrometry. Microchemical Journal. 2003;74:289-97.

24. Liphadzi MS, Kirkham MB. Phytoremediation of soil contaminated with heavy metals: a technology for rehabilitation of the environment. South African Journal of Botany. 2005;71(1):24-37.

25. Rachmadiarti F, Trimulyono. Phytoremediation capability of water clover (Marsilea crenata (L). Pesl.) in synthetic Pb solution. Applied Ecology and Environmental Research. 2019;17(4):9609-9619.

26. Nishida S, Tsuzuki C, Kato A, Aisu A, Yoshida J, Mizuno T. AtIRT1, the primary iron uptake rransporter in the root, mediates excess nickel accumulation in Arabidopsis thaliana. Plant Cell Physiol. 2011;52:1433-42.

27. Adamczyk-Szabela D, Markiewicz J, Wolf WM. Heavy metal uptake by herbs. IV. Infl uence of soil pH on the content of heavy metals in Valeriana officinalis $\mathrm{L}$. Water Air Soil Pollut. 2015;226(4):106.

28. Rachmadiarti F, Trimulyono G. The efficacy of Salvinia molesta Mitch. and Marsilea crenata Presl. as phytoremediators of lead pollution. Journal of Applied Horticulture. 2018;20(1):48-51. 


\section{GRAPHICAL ABSTRACT}

Analysis of Heavy Metal Contents of Marsilea crenata Presl. Leaves and Soils from Java Province, Indonesia

\begin{tabular}{|c|c|c|c|c|c|}
\hline \multicolumn{7}{|c|}{ Demography of areas of cultivation } \\
\hline No. & Area & Soil Type & $\begin{array}{c}\text { Elevation } \\
(\mathbf{m a s})\end{array}$ & $\begin{array}{c}\text { Rainfall/Year } \\
(\mathbf{m m})\end{array}$ & $\begin{array}{c}\text { Temperature } \\
\left({ }^{\circ} \mathbf{C}\right)\end{array}$ \\
\hline 1 & Batu District, Batu City & Andosol & $900-1000$ & $2001-2500$ & $24-26$ \\
\hline 2. & $\begin{array}{c}\text { Purwodadi District, } \\
\text { Pasuruan City }\end{array}$ & Alluvial & $350-700$ & $2001-2500$ & $25-32$ \\
\hline 3 & $\begin{array}{c}\text { Benowo District, } \\
\text { Surabaya City }\end{array}$ & Alluvial & $20-30$ & $1001-1500$ & $24-32$ \\
\hline 4 & $\begin{array}{c}\text { Wates District, Kediri } \\
\text { City }\end{array}$ & Regosol & $50-60$ & $15001-2000$ & $23-30$ \\
\hline
\end{tabular}
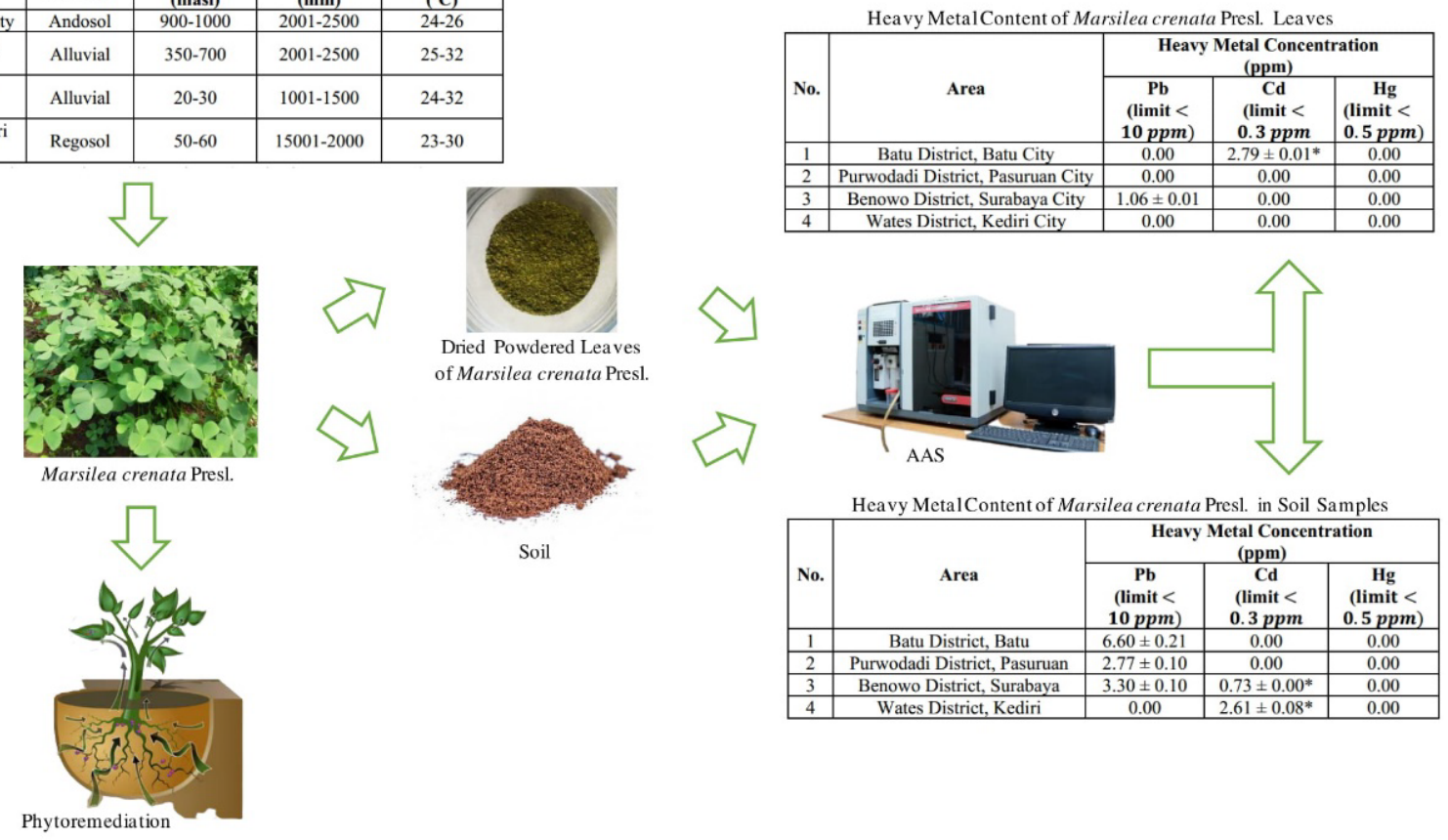

\section{ABOUT AUTHORS}

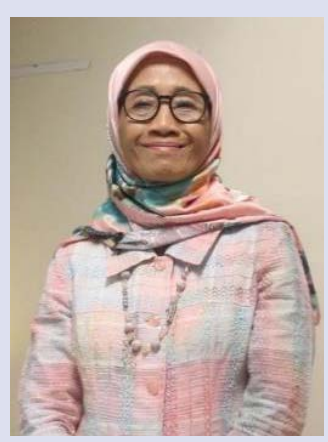

Prof. Dr. apt. Mangestuti Agil, M.S: Lecturer and Researcher at Department of Pharmacognosy and Phytochemistry, Faculty of Pharmacy, Universitas Airlangga, Surabaya 60115, Indonesia.



Prof. Dr. dr. Hening Laswati, Sp.KFR (K): Lecturer and Researcher at Department of Physical Medicine and Rehabilitation, Faculty of Medicine, Universitas Airlangga, Surabaya 60115, Indonesia. 


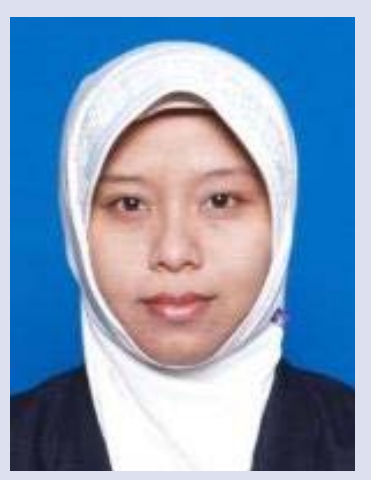

apt. Neny Purwitasari, S.Farm., M.Sc: Lecturer and Researcher at Department of Pharmacognosy and Phytochemistry, Faculty of Pharmacy, Universitas Airlangga, Surabaya 60115, Indonesia.

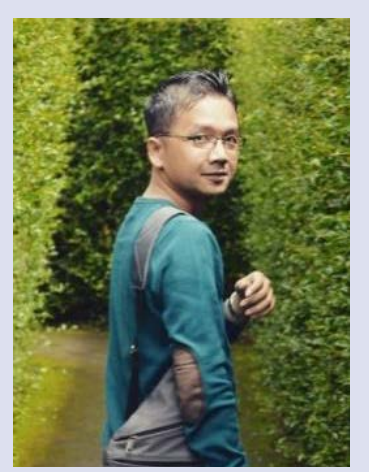

Dr. apt. Burhan Ma'arif, M.Farm: Lecturer and Researcher at Department of Pharmacy, Faculty Medical and Health Science, Maulana Malik Ibrahim State Islamic University, Malang 65144, Indonesia.

Cite this article: Agil M, Laswati H, Purwitasari N, Ma'arif B. Analysis of Heavy Metal Contents of Marsilea crenata Presl. Leaves and Soils from East Java Province, Indonesia. Pharmacog J. 2021;13(1): 17-22. 